\title{
The World Society of Emergency Surgery (WSES) spleen trauma classification: a useful tool in the management of splenic trauma
}

Federico Coccolini ${ }^{1,2^{*}}$, Paola Fugazzola ${ }^{1,2}$, Lucia Morganti ${ }^{3}$, Marco Ceresoli ${ }^{1,4}$, Stefano Magnone ${ }^{2}$, Giulia Montori ${ }^{2}$, Matteo Tomasoni ${ }^{1,2}$, Stefano Maccatrozzo ${ }^{2}$, Niccolò Allievi ${ }^{2}$, Savino Occhionorelli ${ }^{3}$, Yoram Kluger ${ }^{4}$, Massimo Sartelli ${ }^{5}$, Gian Luca Baiocchi', Luca Ansaloni ${ }^{1,2}$ and Fausto Catena ${ }^{7}$

\begin{abstract}
Background: The World Society of Emergency Surgery (WSES) spleen trauma classification meets the need of an evolution of the current anatomical spleen injury scale considering both the anatomical lesions and their physiologic effect. The aim of the present study is to evaluate the efficacy and trustfulness of the WSES classification as a tool in the decision-making process during spleen trauma management.

Methods: Multicenter prospective observational study on adult patients with blunt splenic trauma managed between 2014 and 2016 in two Italian trauma centers (ASST Papa Giovanni XXIII in Bergamo and Sant'Anna University Hospital in Ferrara). Risk factors for operative management at the arrival of the patient and as a definitive treatment were analyzed. Moreover, the association between the different WSES grades of injury and the definitive management was analyzed.
\end{abstract}

Results: One hundred twenty-four patients were included. At multivariate analysis, a WSES splenic injury grade IV is a risk factor for the operative management both at the arrival of the patients and as a definitive treatment. WSES splenic injury grade III is a risk factor for angioembolization.

Conclusions: The WSES classification is a good and reliable tool in the decision-making process in splenic trauma management.

Keywords: Spleen trauma, Classification, Validation, Practice, Surgery, Outcome, Non-operative management, Quality

\section{Introduction}

The most commonly used classification of splenic trauma is the American Association for the Surgery of Trauma (AAST)-Organ Injury Severity Score (OIS). It was initially ideated to allow the comparison between different series of patients; then, it has been used as a classification system to drive treatment

\footnotetext{
* Correspondence: federico.coccolini@gmail.com

${ }^{1}$ General, Emergency and Trauma Surgery Department, Bufalini Hospital, Viale Ghirotti 268, 47521 Cesena, Italy

${ }^{2}$ General, Emergency and Trauma Surgery Department, Papa Giovanni XXIII Hospital, Bergamo, Italy

Full list of author information is available at the end of the article
}

strategies. It is based on spleen lesion anatomy [1]. This scale was validated by several studies with large sample sizes [2-4] showing as both the management at the patient arrival (operative management $(\mathrm{OM})$ vs non-operative management (NOM)), and the NOM failure rate was associated with the ASST lesion grade in patients with blunt splenic trauma. In fact, the anatomy of the lesions plays a fundamental role in determining the conditions of the patients. In some situations, however, patient conditions lead to an emergent transfer to the operating room (OR) without the opportunity to define the grade of splenic lesions before the surgical exploration. In these cases, 
the physiopathologic status of the patients leads the therapeutic decision, more than the anatomy of the splenic lesions. Moreover, there are patients with high-grade splenic lesions without hemodynamic repercussions that can be managed with NOM thanks to the modern tools in bleeding management. As a counterpart, there exists a cohort of patients with hemodynamic instability requiring urgent surgical intervention due to low-grade splenic injuries. In May 2017, during the World Society of Emergency Surgery (WSES) World Congress in Campinas, Brazil, the final version of the WSES guidelines on spleen trauma was approved (Fig. 1) [5]. The WSES grading system takes into account both the patient's condition and the anatomy of lesions.

The aim of the present study is to evaluate the efficacy and trustfulness of the WSES classification as a tool in decision-making process during spleen trauma management.

\section{Methods}

This is an analysis of two prospectively enrolled adult patient cohorts with blunt splenic trauma managed between 2014 and 2016 in two Italian trauma centers (TC) (ASST Papa Giovanni XXIII in Bergamo and Sant'Anna University Hospital in Ferrara) stratified according to the WSES classification. Ethical committee and patients' consent to participate were waived because no personal or sensible data were recorded and no specific intervention was adopted other than the usual clinical practice. Patients' characteristics were collected (age, sex, comorbidity, ASA (American Society of Anesthesiologists) score, antiplatelet or anticoagulant therapy). Trauma mechanism of injury, patient conditions at the arrival in the emergency department (ED) (systolic blood pressure (SBP), heart rate (HR), shock index (SI), need of red blood cell (RBC) transfusion), blood gas test $(\mathrm{pH}$, base excess $(\mathrm{BE})$, lactates (Lac)), blood exams (CBC, platelet count, INR, fibrinogen), and eco-fast results were reported. We defined a patient "hemodynamically unstable" if, after resuscitation in the ED and without vasoactive drugs, he/she had a SBP lower than 90 mmHg, a shock index higher than 1 , or a $\mathrm{BE}$ lower than -5 .

For patients who underwent $\mathrm{CT}$ at the arrival, the AAST classification for the splenic injury, the number of abdominal quadrants with hemoperitoneum, and the presence of vascular lesions (contrast blush $(\mathrm{CB})$, pseudoaneurysm (PSA), arterovenous fistula (AVF)) were reported. For patients who underwent urgent surgical intervention, intraoperative (for splenectomized patients) or postoperative CT findings were registered. The Injury Severity Score (ISS) and the presence of associated abdominal, pelvic, or cerebral lesions were reported. Patients were classified according to the 2017 WSES classification. The management at the arrival (observation, distal angioembolization $(\mathrm{AE})$, proximal $\mathrm{AE}$, splenectomy, intraperitoneal packing, hemostasis of the splenic injury, surgical intervention for other organ lesions), the time between the arrival in the ED and the first urgent intervention, and the need of further intervention during hospital stay ( $\mathrm{AE}$ or splenectomy) have been recorded.

It was defined $\mathrm{OM}$ if the patient underwent urgent surgical intervention at the arrival at the ED and if during the surgical procedure, a splenectomy or a hemostatic splenic technique (e.g., splenic packing or splenorrhaphy) was performed. The NOM could include $\mathrm{AE}$ or not. Failure of NOM (fNOM) was defined as the

\section{SPLEEN}

\begin{tabular}{|c|c|c|c|}
\hline & WSES class & AAST & Haemodynamic \\
\hline \multirow{2}{*}{ MINOR } & WSES I & I - II & Stable \\
\hline \multirow{2}{*}{ MODERATE } & WSES II & III & Stable \\
\cline { 2 - 4 } & WSES III & IV - V & Stable \\
\hline \multirow{2}{*}{ SEVERE } & WSES IV & I-V & Unstable \\
\hline
\end{tabular}

Fig. 1 WSES Spleen trauma classification 
Table 1 Patient characteristics

\begin{tabular}{l} 
Characteristics \\
\hline Age (years) \\
M/F \\
Trauma mechanism of injury \\
-Invested pedestrian \\
-Car \\
-Motorbike \\
-Bike \\
-Precipitation \\
-Others \\
ISS
\end{tabular}

HR at arrival in ED (bpm)

SBP at arrival in $\mathrm{ED}(\mathrm{mmHg})$

$\mathrm{pH}$

$\mathrm{BE}(\mathrm{mmol} / \mathrm{L})$

Lac

$\mathrm{Hb}(\mathrm{g} / \mathrm{dL})$

INR (s)

Fibrinogen (mg/dL)

Platelets $\left(\times 10^{3} / \mathrm{mL}\right)$

Number of RBC units transfused in $E D$
$N=124$ Mean \pm SD Median (range)

$50.23 \pm 18.36$

48.68

(17.00-91.00)

$91 / 33$

$(73.4 \% / 26.6 \%)$

$11(8.9 \%)$

$38(30.6 \%)$

$39(31.5 \%)$

$5(4.0 \%)$

$17(13.7 \%)$

$14(11.3 \%)$

$27.93 \pm 13.02$

27.00

(5.00-75.00)

$90.27 \pm 20.27$

88.00

(48.00-145.00)

$113.91 \pm 25.00$

117.00

(53.00-170.00)

$7.31 \pm 0.12$

7.33

(6.80-7.47)

$-3.23 \pm 3.43$

$-2.8$

$(-14.50$ to +2.10$)$

$3.20 \pm 1.87$

2.92

(0.80-9.24)

$12.53 \pm 2.53$

12.95

(3.30-16.80)

$1.37 \pm 0.72$

1.16

(0.66-5.93)

$231.66 \pm 122.74$

210.00

(26.00-1120.00)

$218.92 \pm 72.27$

220.00

(55.00-460.00)

$0.48 \pm 0.96$
Table 1 Patient characteristics (Continued)

\begin{tabular}{|c|c|}
\hline Characteristics & $\begin{array}{l}N=124 \text { Mean } \pm \mathrm{SD} \\
\text { Median (range) }\end{array}$ \\
\hline & 0.00 \\
\hline & $(0.00-4.00)$ \\
\hline Positive eco-fast & $62(50.0 \%)$ \\
\hline Negative eco-fast negativa & $44(35.5 \%)$ \\
\hline N.A. & $18(14.2 \%)$ \\
\hline AAST 1 & $3(3.2 \%)$ \\
\hline AAST 2 & $48(38.7 \%)$ \\
\hline AAST 3 & $34(27.4 \%)$ \\
\hline AAST 4 & $30(24.2 \%)$ \\
\hline AAST 5 & $5(4.0 \%)$ \\
\hline N.A. & $3(2.4 \%)$ \\
\hline AAST $>3$ & $35(28.2 \%)$ \\
\hline $\mathrm{AAST} \leq 3$ & 87 (70.2\%) \\
\hline WSES I & $44(35.5 \%)$ \\
\hline WSES ॥ & $27(21.8 \%)$ \\
\hline WSES III & $18(14.5 \%)$ \\
\hline WSES IV & $30(24.2 \%)$ \\
\hline N.A. & $5(4.0 \%)$ \\
\hline WSES IV & $30(24.2 \%)$ \\
\hline WSES $<$ IV & $89(71.8 \%)$ \\
\hline Presence of CB & $33(26.6 \%)$ \\
\hline Absence of $C B$ & $74(59.7 \%)$ \\
\hline N.A. & $17(13.7 \%)$ \\
\hline Presence of PSA/FAV & $4(3.2 \%)$ \\
\hline Absence of PSA/FAV & $101(81.5 \%)$ \\
\hline N.A. & $19(15.3 \%)$ \\
\hline \multirow[t]{2}{*}{ Number of quadrants with hemoperitoneum } & $1.59 \pm 1.45$ \\
\hline & $1.00(0.00-5.00)$ \\
\hline Associated abdominal and pelvic lesions & $58(46.8 \%)$ \\
\hline No associated abdominal and pelvic lesions & $66(53.2 \%)$ \\
\hline Associated brain injuries & $24(19.4 \%)$ \\
\hline No associated brain injuries & $100(80.6 \%)$ \\
\hline
\end{tabular}

M/F male/female, ISS Injury Severity Score, $H R$ heart rate, N.A. not available, $S B P$ systolic blood pressure, ED emergency department, $B E$ base excess, $L a c$ lactates, $H b$ hemoglobin, $R B C$ red blood cell, AAST American Association for the Surgery of Trauma, WSES World Society of Emergency Surgery, CB contrast blush, INR International Normalized Ratio

need of performing a splenectomy after starting NOM. To validate the 2017 WSES classification, the risk factors for $\mathrm{OM}$ at the arrival of the patient and for $\mathrm{OM}$ as a definitive treatment (including both patients treated with $\mathrm{OM}$ at the arrival and patients operated for fNOM) have been analyzed. It was verified if the WSES grade was a risk factor for OM at the arrival and as a definitive treatment for adult patients with blunt splenic trauma. 
Table 2 Patient outcomes

\begin{tabular}{|c|c|}
\hline Variable & $\begin{array}{l}N=124 \text { Mean } \pm S D \\
\text { Median (range) }\end{array}$ \\
\hline $\mathrm{NOM}$ & $66(53.2 \%)$ \\
\hline $\mathrm{OM}$ & $58(46.0 \%)$ \\
\hline -Splenectomy & 49 (84.5\%) \\
\hline -Packing/hemostasis & $9(15.5 \%)$ \\
\hline Splenic preservation rate & $67(54.0 \%)$ \\
\hline $\mathrm{AE}$ & $22(17.8 \%)$ \\
\hline -Proximal & $8(36.4 \%)$ \\
\hline -Distal & $11(50.0 \%)$ \\
\hline -Distal + proximal & $2(9.1 \%)$ \\
\hline -N.A. & $1(4.5 \%)$ \\
\hline \multirow{3}{*}{$\begin{array}{l}\text { Time between arrival at the ED and } \\
\text { the first therapeutic procedure (min) }\end{array}$} & $207.65 \pm 295.76$ \\
\hline & 145.00 \\
\hline & (15.00-1920.00) \\
\hline \multirow[t]{3}{*}{ Length of ICU stay (days) } & $9.76 \pm 14.94$ \\
\hline & 5.00 \\
\hline & $(0.00-87.00)$ \\
\hline \multirow[t]{3}{*}{ Total length of stay (days) } & $20.01 \pm 18.21$ \\
\hline & 14.00 \\
\hline & $(0.50-90.00)$ \\
\hline fNOM $(N=63)$ & $8(12.7 \%)$ \\
\hline Complications & $47(41.2 \%)$ \\
\hline Global mortality & $13(10.5 \%)$ \\
\hline Specific mortality & $0(0.0 \%)$ \\
\hline
\end{tabular}

NOM non-operative management, OM operative management, $N . A$. not available, FNOM failure of non-operative management, ICU intensive care unit

\section{Statistical analysis}

Continuous variables were expressed as mean and standard deviation; categorical data were expressed as proportions and percentages. $t$ test was used for continuous variables with normal distribution and the Mann-Whitney test for non-normal distribution variables. Parametric variables were compared with chisquare test. Multivariate models were calculated with the linear logistic regression method including all the variables resulted significantly associated $(p<0.05)$ with the selected outcome at univariate analysis. All the statistical analysis was performed with IBM SPSS 20 (IBM Corp. released 2011; IBM SPSS Statistics for Windows, Version 20.0; Armonk, NY: IBM Corp.).

\section{Results}

The study includes 124 patients older than 17 years with blunt splenic lesion, of whom 66 managed in ASST Papa Giovanni in Bergamo and 58 in Sant'Anna University Hospital in Ferrara. The two groups of patients were similar in terms of epidemiological features, trauma mechanism of injury, ISS, and splenic injury grade. Patient characteristics are reported in Table 1.

NOM rate was 53.2\% (66 patients) and $\mathrm{OM}$ rate 46.0\% (58 patients). Among OM patients, we had 84.5\% (49 patients) of patients treated with splenectomy and $15.5 \%$ (9 patients) with hepatic and splenic packing (in patients with hepatic lesion associated) and/or splenic hemostasis (Table 2).

Among NOM patients, 22 underwent AE $(17.8 \%$ of total patients and $33.3 \%$ of NOM patients) at the arrival or during the hospital stay (Table 2).

Risk factors for OM at the arrival of patient in the ED, including the WSES splenic injury grade, were analyzed with univariate (Table 3) and multivariate (Table 4) analysis.

At the multivariate analysis, the WSES IV splenic injury grade was found as the only one risk factor for $\mathrm{OM}$ at the arrival of patients (OR 5.44, $p=0,049$ ) (Table 4).

The risk factors for $\mathrm{OM}$ as a definitive treatment were analyzed, including both patients treated with $\mathrm{OM}$ at the arrival in the ED and patients operated for fNOM. The OM was applied on $53.2 \%$ of patients as a definitive treatment.

Risk factors emerging from univariate and multivariate analyses are shown in Tables 5 and 6 .

The WSES grade IV (OR 7.22, $p=0,029)$ and ISS value higher than 25 (OR 5.75, $p=0,013$ ) were found as the only significant risk factors at the multivariate analysis (Table 6).

The previous analysis showed as OM rate, both at the arrival of patient and as a definitive treatment, increased with the increasing of the WSES splenic injury grade, in particular for the WSES grade IV compared with lower grade (Figs. 2 and 3).

The present study verified also if the AAST and WSES classifications were predictive for AE at the arrival of patient with splenic injury or during hospital stay. While an AAST grade higher than 3 was not a significant risk factor for AE (AAST > $3(20.0 \%)$ vs AAST $\leq 3(17.2 \%)$, n.s.), a WSES splenic injury grade of III was found as a significant risk factor (WSES 3 (38.9\%) vs WSES $1-2-4(13.9 \%), p=0.010)$.

\section{Discussion}

After the introduction of $\mathrm{AE}$ and the modern tools in bleeding management, the NOM failure rate decreased from $23-67 \%$ to $4-42 \%$ [6-10] and it was no longer associated with the AAST injury grade (i.e., anatomical degree of lesion) [11]. So it has been accepted that the physiopathologic status of the patients, more than the anatomy of the splenic lesions, should lead the therapeutic decision in splenic 
Table 3 Univariate analysis of risk factors for $\mathrm{OM}$ at the arrival of patient at the ED

\begin{tabular}{|c|c|c|c|}
\hline \multirow[t]{2}{*}{ Variable } & \multicolumn{2}{|c|}{ Mean \pm SD Median (range) } & \multirow[t]{2}{*}{$p$ value } \\
\hline & NOM & $\mathrm{OM}$ & \\
\hline Age $<55$ years & $42.3 \%$ & $57.7 \%$ & n.s. \\
\hline Age $>55$ years & $50.0 \%$ & $50.0 \%$ & \\
\hline \multirow[t]{2}{*}{ Age (years) } & $50.54 \pm 18.17$ & $49.87 \pm 18.73$ & n.s. \\
\hline & 49.35 (18.00-91.00) & $48.00(17.00-85.60)$ & \\
\hline $\begin{array}{l}\text { No anticoagulant/antiplatelet } \\
\text { drugs }\end{array}$ & $48.8 \%$ & $51.2 \%$ & n.s. \\
\hline $\begin{array}{l}\text { Anticoagulant/antiplatelet } \\
\text { drugs }\end{array}$ & $40.0 \%$ & $60.0 \%$ & \\
\hline $\mathrm{HR}($ mean $\pm \mathrm{SD})$ & $85.95 \pm 18.66$ & $95.24 \pm 21.07$ & 0.009 \\
\hline Median (range) (bpm) & $\begin{array}{l}80.00(48.00- \\
133.00)\end{array}$ & $\begin{array}{l}95.00(55.00- \\
145.00)\end{array}$ & \\
\hline $\mathrm{HR}<120 \mathrm{bpm}$ & $58.7 \%$ & $41.3 \%$ & n.s. \\
\hline $\mathrm{HR}>120 \mathrm{bpm}$ & $46.8 \%$ & $53.2 \%$ & \\
\hline \multirow[t]{2}{*}{$\mathrm{SBP}(\mathrm{mmHg})$} & $120.40 \pm 21.35$ & $106.51 \pm 26.92$ & 0.002 \\
\hline & $\begin{array}{l}120.00(70.00- \\
170.00)\end{array}$ & $\begin{array}{l}105.00(53.00- \\
167.00)\end{array}$ & \\
\hline $\mathrm{SBP}>90 \mathrm{mmHg}$ & $60.4 \%$ & $39.6 \%$ & 0.001 \\
\hline $\mathrm{SBP}<90 \mathrm{mmHg}$ & $21.7 \%$ & $78.3 \%$ & \\
\hline Shock index $<1$ & $60.2 \%$ & $39.8 \%$ & 0.002 \\
\hline Shock index $>1$ & $26.9 \%$ & $73.1 \%$ & \\
\hline AAST 1 & $100.0 \%$ & $0.0 \%$ & $<0.001$ \\
\hline AAST 2 & $81.3 \%$ & $18.7 \%$ & \\
\hline AAST 3 & $44.1 \%$ & $55.9 \%$ & \\
\hline AAST 4 & $26.7 \%$ & $73.3 \%$ & \\
\hline AAST 5 & $0.0 \%$ & $100.0 \%$ & \\
\hline $\mathrm{AAST} \leq 3$ & $66.7 \%$ & $33.3 \%$ & $<0.001$ \\
\hline $\mathrm{AAST}>3$ & $22.9 \%$ & $77.1 \%$ & \\
\hline WSES I & $86.4 \%$ & $13.6 \%$ & $<0.001$ \\
\hline WSES ॥ & $44.4 \%$ & $55.6 \%$ & \\
\hline WSES III & $44.4 \%$ & $55.6 \%$ & \\
\hline WSES IV & $20.0 \%$ & $80.0 \%$ & \\
\hline WSES I-II-III & $63.8 \%$ & $36.2 \%$ & $<0.001$ \\
\hline WSES IV & $20.0 \%$ & $80.0 \%$ & \\
\hline \multirow[t]{2}{*}{ ISS } & $24.38 \pm 12.68$ & $32.05 \pm 12.27$ & $<0.001$ \\
\hline & $22.00(5.00-75.00)$ & $29.00(9.00-66.00)$ & \\
\hline ISS $<25$ & $72.0 \%$ & $28.0 \%$ & 0.001 \\
\hline ISS $>25$ & $40.9 \%$ & $59.1 \%$ & \\
\hline \multirow[t]{2}{*}{ Lac } & $3.01 \pm 1.90$ & $3.51 \pm 1.85$ & n.s. \\
\hline & $2.66(0.80-9.24)$ & $3.08(1.30-8.00)$ & \\
\hline \multirow[t]{2}{*}{$\mathrm{BE}(\mathrm{mmol} / \mathrm{L})$} & $-3.34 \pm 3.82$ & $-3.06 \pm 2.88$ & n.s. \\
\hline & $\begin{array}{l}-2.80(-14.50- \\
2.10)\end{array}$ & $\begin{array}{l}-2.90(-9.50- \\
1.80)\end{array}$ & \\
\hline \multirow[t]{2}{*}{$\mathrm{pH}$} & $7.32 \pm 0.07$ & $7.28 \pm 0.16$ & n.s. \\
\hline & $7.34(7.13-7.43)$ & $7.29(6.80-7.47)$ & \\
\hline \multirow[t]{2}{*}{$\mathrm{Hb}(\mathrm{g} / \mathrm{dL})$} & $13.31 \pm 2.33$ & $11.39 \pm 2.63$ & $<0.001$ \\
\hline & $13.60(5.60-16.80)$ & $11.70(3.30-16.40)$ & \\
\hline $\mathrm{Hb}>12 \mathrm{~g} / \mathrm{dL}$ & $66.7 \%$ & $33.3 \%$ & 0.001 \\
\hline $\mathrm{Hb} \leq 12 \mathrm{~g} / \mathrm{dL}$ & $37.9 \%$ & $62.1 \%$ & \\
\hline
\end{tabular}

Table 3 Univariate analysis of risk factors for $\mathrm{OM}$ at the arrival of patient at the ED (Continued)

\begin{tabular}{|c|c|c|c|}
\hline \multirow[t]{2}{*}{ Variable } & \multicolumn{2}{|c|}{ Mean \pm SD Median (range) } & \multirow[t]{2}{*}{$p$ value } \\
\hline & $\overline{\mathrm{NOM}}$ & $\mathrm{OM}$ & \\
\hline$\overline{\mathrm{BE}}>-5 \mathrm{mmol} / \mathrm{L}$ & $57.7 \%$ & $42.3 \%$ & \multirow[t]{2}{*}{ n.s. } \\
\hline $\mathrm{BE}<-5 \mathrm{mmol} / \mathrm{L}$ & $66.7 \%$ & $33.3 \%$ & \\
\hline Brain injuries & $41.7 \%$ & $58.3 \%$ & \multirow[t]{2}{*}{ n.s. } \\
\hline No brain injuries & $56.0 \%$ & $44.0 \%$ & \\
\hline Associated abdominal lesions & $44.8 \%$ & $55.2 \%$ & \multirow[t]{2}{*}{ n.s. } \\
\hline $\begin{array}{l}\text { No associated abdominal } \\
\text { lesions }\end{array}$ & $60.6 \%$ & $39.4 \%$ & \\
\hline \multicolumn{3}{|l|}{ Trauma mechanism of injury } & \multirow[t]{7}{*}{ n.s. } \\
\hline -Invested pedestrian & $72.7 \%$ & $27.3 \%$ & \\
\hline -Car & $44.7 \%$ & $55.3 \%$ & \\
\hline -Motorbike & $56.4 \%$ & $43.6 \%$ & \\
\hline -Bike & $60.0 \%$ & $40.0 \%$ & \\
\hline -Precipitation & $52.9 \%$ & $47.1 \%$ & \\
\hline -Others & $50.0 \%$ & $50.0 \%$ & \\
\hline Contrast blush & $42.4 \%$ & $57.6 \%$ & \multirow[t]{2}{*}{0.010} \\
\hline No contrast blush & $68.9 \%$ & $31.1 \%$ & \\
\hline Pseudoaneurysm & $50.0 \%$ & $50.0 \%$ & \multirow[t]{2}{*}{ n.s. } \\
\hline No pseudoaneurysm & $61.4 \%$ & $38.6 \%$ & \\
\hline Hemoperitoneum at TC & $54.4 \%$ & $45.6 \%$ & n.s. \\
\hline \multicolumn{4}{|c|}{ Number of quadrants with hemoperitoneum } \\
\hline$->1$ & $42.0 \%$ & $58.0 \%$ & \multirow[t]{2}{*}{$<0.001$} \\
\hline$-\leq 1$ & $69.4 \%$ & $30.6 \%$ & \\
\hline \multirow[t]{2}{*}{ INR (s) } & $1.12 \pm 0.15$ & $1.69 \pm 1.11$ & \multirow[t]{2}{*}{0.001} \\
\hline & $1.15(0.66-1.38)$ & $1.23(1.04-5.05)$ & \\
\hline INR $>1.5 \mathrm{~s}$ & $23.5 \%$ & $76.5 \%$ & \multirow[t]{2}{*}{0.014} \\
\hline INR $<1.5 \mathrm{~s}$ & $55.7 \%$ & $44.3 \%$ & \\
\hline \multirow[t]{2}{*}{ Fibrinogen (mg/dL) } & $215.52 \pm 53.98$ & $168.23 \pm 67.51$ & \multirow[t]{2}{*}{0.020} \\
\hline & $\begin{array}{l}205.00(156.0- \\
491.00)\end{array}$ & $\begin{array}{l}173.00(26.00- \\
260.00)\end{array}$ & \\
\hline Fibrinogen $\leq 200 \mathrm{mg} / \mathrm{dL}$ & $38.1 \%$ & $61.9 \%$ & \multirow[t]{2}{*}{0.031} \\
\hline Fibrinogen $>200 \mathrm{mg} / \mathrm{dL}$ & $60.4 \%$ & $39.6 \%$ & \\
\hline \multirow[t]{2}{*}{$\mathrm{PLT} / \mathrm{mm}^{3}$} & $217.38 \pm 49.76$ & $198.29 \pm 83.93$ & \multirow[t]{2}{*}{ n.s. } \\
\hline & $\begin{array}{l}220.00(137.00- \\
315.00)\end{array}$ & $\begin{array}{l}190.00(156.00- \\
401.00)\end{array}$ & \\
\hline Positive eco-fast & $33.9 \%$ & $66.1 \%$ & \multirow[t]{2}{*}{$<0.001$} \\
\hline Negative eco-fast & $72.7 \%$ & $27.3 \%$ & \\
\hline $\mathrm{RBC}$ transfusion at the $\mathrm{ED}$ & $34.6 \%$ & $65.4 \%$ & \multirow[t]{2}{*}{0.032} \\
\hline No RBC transfusion at the ED & $58.2 \%$ & $41.8 \%$ & \\
\hline
\end{tabular}

ISS Injury Severity Score, $H R$ heart rate, SBP systolic blood pressure, ED emergency department, $B E$ base excess, $L a c$ lactates, $H b$ hemoglobin, $R B C$ red blood cell, AAST American Association for the Surgery of Trauma, WSES World Society of Emergency Surgery, PLT platelet, INR International Normalized Ratio

trauma. Furthermore, many studies [8, 12-16] showed that the vascular lesions (CB, PSA, AVF), which have significant incidence also in low-grade injuries $[12,16]$, were predictive factors for NOM failure and that they should be considered indications to 
Table 4 Multivariate analysis of risk factors for $\mathrm{OM}$ at the arrival of patient at the ED

\begin{tabular}{lll}
\hline Variables & $p$ value & OR \\
\hline ISS $>25$ & n.s. & $/$ \\
Contrast blush & n.s. & $/$ \\
Positive e-fast & n.s. & $/$ \\
RBC transfusion in ED & n.s. & $/$ \\
Fibrinogen $\leq 200 \mathrm{mg} / \mathrm{dL}$ & n.s. & $/$ \\
INR $>1.5 \mathrm{~s}$ & n.s. & $/$ \\
Quadrants with hemoperitoneum $>1$ & n.s. & $/$ \\
Hb $\leq 12 \mathrm{~g} / \mathrm{dL}$ & n.s. & 5.44 \\
WSES IV & 0.049 &
\end{tabular}

ISS Injury Severity Score, $C B$ contrast blush, ED emergency department, $R B C$ red blood cell, SI shock index, AAST American Association for the Surgery of Trauma, $\mathrm{H} b$ hemoglobin, WSES World Society of Emergency Surgery, INR International Normalized Ratio

AE. Vascular lesions are not considered in the AAST classification. The WSES spleen trauma classification considers both the anatomical injury grade and the clinical conditions of the patients, so it can be considered as a complete tool to lead splenic trauma management, especially if associated to dedicated guidelines. From the analysis emerged, all the factors related to $\mathrm{OM}$ and $\mathrm{fNOM}$ are those linked to the physiology of the patients and more than the anatomy. AAST classes related to the OM $+\mathrm{fNOM}$ mainly for the anatomical basis that represents a proxy even of the physiological conditions. WSES classes consider even the physiology from the beginning, and in fact, the patient stratification is slightly different (Table 5).

Actually, in fact, the possibility to not operate spleen trauma and to manage them with NOM is becoming mandatory in right patients and in all those systems where enough facilities are present. The NOM percentage can furthermore be considered as a proxy of the preparedness of the system to manage with severe trauma with advanced strategies, allowing preserving as many patients as possible from operative procedures. To obtain this result is necessary to set a system where classification and management of traumatized patients are driven by updated patient stratification tool and guidelines. Present classification associated to the last released guidelines might definitively allow for an improvement in spleen injured patient management. As showed in the analysis, in fact, it more strictly adheres to the necessities of the common clinical practice. As a counterpart, however, the variability within the different members even from a single department accounts for the real life data.

Population of the present study represents the typical case mix of two Italian trauma centers. The cases presented in Italy are the most part victim of blunt trauma. In general, few penetrating traumas are treated in Italian hospitals. The NOM rate reported in literature ranged from 60 to 95\% [17-20] and includes both studies conducted in structures with local protocols for splenic trauma management and study conducted in structures in which trauma management was based on the single surgeon experience and common sense. Present study renders the actual situation in management of splenic injury in trauma centers without the application of a shared guideline, and so it gives a good representation of the real situation. The NOM rate is $53.2 \%$, and it can be considered a not-high rate. In fact, even patients with low injury grade were splenectomized. Present data showed, even in this context, as the WSES spleen injury grade IV is a significant risk factor for OM, both at the arrival of the patients and as a definitive treatment. Furthermore, a WSES spleen injury grade III is a risk factor for AE (WSES 3 $(38.9 \%)$ vs WSES 1-2-4 (13.9\%), $p=0.010)$. WSES grade IV represents the only factor related to the $\mathrm{OM}$ as management at the patient admission. In fact, the hemodynamic status is the only determinant of the necessity to proceed to operating room. The anatomical grade of damage is not influent on the emergency management in presence of hemodynamic instability at admission. However, the relative high $\mathrm{OM}$ rate, also in lower injury grade (OM rate is $36.2 \%$ in WSES I,I, and III injury grade), reflects the need for standardized and widely shared guideline in order to increase conservative management. Even if in presence of such a big variability in patient management, the WSES classification showed to be effective in driving the management. Therefore, the benefits deriving from the use the WSES trauma spleen classification could have their greatest expression if associated with the application of the widely approved WSES spleen trauma guidelines. Their combined large-scale application could realistically increase successful NOM rate and improve the spleen trauma management.

The limitations of this study are that this is an observational study, even if prospective, and that patients did not have isolated spleen injury and so the associated lesions could have partially influenced results; however, as said, it reports the reality in the trauma centers' daily practice. As a counterpart, however, this study stresses the necessity to diffuse and apply a common way to proceed. This will allow to reduce the number of operated patients and to improve the management quality by reducing even the short- and long-term morbi-mortality of unnecessary laparotomies and splenectomies. 
Table 5 Univariate analysis for $\mathrm{OM}$ as a definitive treatment

\begin{tabular}{|c|c|c|c|}
\hline \multirow[t]{2}{*}{ Characteristics } & \multicolumn{2}{|c|}{ Mean \pm SD Median (range) } & \multirow[t]{2}{*}{$p$ value } \\
\hline & Successful NOM & $\mathrm{OM}+\mathrm{fNOM}$ & \\
\hline WSES I & $79.5 \%$ & $20.5 \%$ & $<0.001$ \\
\hline WSES ॥ & $33.3 \%$ & $66.7 \%$ & \\
\hline WSES III & $27.8 \%$ & $72.2 \%$ & \\
\hline WSES IV & $13.3 \%$ & $86.7 \%$ & \\
\hline ASST 1 & $100.0 \%$ & $00.0 \%$ & $<0.001$ \\
\hline ASST 2 & $68.8 \%$ & $31.2 \%$ & \\
\hline ASST 3 & $35.3 \%$ & $64.7 \%$ & \\
\hline ASST 4 & $16.7 \%$ & $83.3 \%$ & \\
\hline ASST 5 & $0.0 \%$ & $100.0 \%$ & \\
\hline WSES I-II-III & $53.2 \%$ & $46.8 \%$ & $<0.001$ \\
\hline WSES IV & $13.3 \%$ & $86.7 \%$ & \\
\hline ASST $\leq 3$ & $56.3 \%$ & $43.7 \%$ & $<0.001$ \\
\hline ASST $>3$ & $14.3 \%$ & $85.7 \%$ & \\
\hline \multirow[t]{2}{*}{ Age (years) } & $48.79 \pm 17.94$ & $51.36 \pm 18.74$ & n.s. \\
\hline & $\begin{array}{l}47.63(18.00- \\
87.00)\end{array}$ & $\begin{array}{l}49.00(17.00- \\
91.00)\end{array}$ & \\
\hline $\begin{array}{l}\text { No anticoagulant/ } \\
\text { antiplatelet drugs }\end{array}$ & $39.29 \%$ & $60.71 \%$ & n.s. \\
\hline $\begin{array}{l}\text { Anticoagulant/antiplatelet } \\
\text { drugs }\end{array}$ & $40.00 \%$ & $60.00 \%$ & \\
\hline \multirow[t]{2}{*}{ HR (bpm) } & $85.57 \pm 17.94$ & $93.87 \pm 21.32$ & 0.039 \\
\hline & $\begin{array}{l}85.00(48.00- \\
133.00)\end{array}$ & $\begin{array}{l}90.00(55.00- \\
145.00)\end{array}$ & \\
\hline $\mathrm{HR}<120 \mathrm{bpm}$ & $48.00 \%$ & $52.00 \%$ & n.s. \\
\hline $\mathrm{HR}>120 \mathrm{bpm}$ & $38.30 \%$ & $61.70 \%$ & \\
\hline \multirow[t]{2}{*}{$\mathrm{SBP}(\mathrm{mmHg})$} & $122.21 \pm 20.18$ & $107.54 \pm 26.57$ & 0.001 \\
\hline & $\begin{array}{l}120.00(70.00- \\
170.00)\end{array}$ & $\begin{array}{l}110.00(53.00- \\
167.00)\end{array}$ & \\
\hline $\mathrm{SBP}>90 \mathrm{mmHg}$ & $50.5 \%$ & $49.5 \%$ & $<0.001$ \\
\hline $\mathrm{SBP}<90 \mathrm{mmHg}$ & $13.0 \%$ & $87.0 \%$ & \\
\hline Shock index $<1$ & $51.0 \%$ & $49.0 \%$ & 0.021 \\
\hline Shock index $>1$ & $15.4 \%$ & $84.6 \%$ & \\
\hline \multirow[t]{2}{*}{ ISS } & $21.89 \pm 10.25$ & $32.81 \pm 13.02$ & $<0.001$ \\
\hline & $22.00(5.00-48.00)$ & $\begin{array}{l}29.00(9.00- \\
75.00)\end{array}$ & \\
\hline ISS $<25$ & $70.0 \%$ & $30.0 \%$ & $<0.001$ \\
\hline ISS $>25$ & $26.8 \%$ & $73.2 \%$ & \\
\hline \multirow[t]{2}{*}{ Lactate } & $2.99 \pm 1.96$ & $3.45 \pm 1.78$ & n.s. \\
\hline & $2.44(0.80-9.24)$ & $3.08(1.27-8.00)$ & \\
\hline \multirow[t]{2}{*}{$\mathrm{BE}(\mathrm{mmol} / \mathrm{L})$} & $-3.07 \pm 3.87$ & $-3.40 \pm 2.94$ & n.s. \\
\hline & $\begin{array}{l}-2.80(-14.50- \\
2.10)\end{array}$ & $\begin{array}{l}-3.10(-9.50- \\
1.80)\end{array}$ & \\
\hline \multirow[t]{2}{*}{$\mathrm{pH}$} & $7.32 \pm 0.08$ & $7.29 \pm 0.15$ & n.s. \\
\hline & $7.34(7.13-7.43)$ & $7.31(6.80-7.47)$ & \\
\hline \multirow[t]{2}{*}{$\mathrm{Hb}(\mathrm{g} / \mathrm{dL})$} & $13.78 \pm 1.88$ & $11.29 \pm 2.66$ & $<0.001$ \\
\hline & $14.1(10.10-16.80)$ & $\begin{array}{l}11.60(3.30- \\
16.40)\end{array}$ & \\
\hline $\mathrm{Hb} \leq 12 \mathrm{~g} / \mathrm{dL}$ & $24.1 \%$ & $75.9 \%$ & $<0.001$ \\
\hline
\end{tabular}

Table 5 Univariate analysis for $\mathrm{OM}$ as a definitive treatment (Continued)

\begin{tabular}{|c|c|c|c|}
\hline \multirow[t]{2}{*}{ Characteristics } & \multicolumn{2}{|c|}{ Mean \pm SD Median (range) } & \multirow[t]{2}{*}{$p$ value } \\
\hline & Successful NOM & $\mathrm{OM}+\mathrm{fNOM}$ & \\
\hline $\mathrm{Hb}>12 \mathrm{~g} / \mathrm{dL}$ & $60.6 \%$ & $39.4 \%$ & \\
\hline $\mathrm{BE}>-5 \mathrm{mmol} / \mathrm{L}$ & $57.7 \%$ & $42.3 \%$ & n.s. \\
\hline $\mathrm{BE}<-5 \mathrm{mmol} / \mathrm{L}$ & $50.0 \%$ & $50.0 \%$ & \\
\hline Brain injuries & $29.2 \%$ & $70.8 \%$ & n.s. \\
\hline No brain injuries & $47.0 \%$ & $53.0 \%$ & \\
\hline $\begin{array}{l}\text { Associated abdominal } \\
\text { lesions }\end{array}$ & $36.2 \%$ & $63.8 \%$ & n.s. \\
\hline $\begin{array}{l}\text { No associated abdominal } \\
\text { lesions }\end{array}$ & $50.0 \%$ & $50.0 \%$ & \\
\hline Trauma dynamic & & & n.s. \\
\hline -Invested pedestrian & $45.5 \%$ & $54.5 \%$ & \\
\hline$-\mathrm{Car}$ & $26.3 \%$ & $73.7 \%$ & \\
\hline -Motorbike & $53.9 \%$ & $46.1 \%$ & \\
\hline -Bike & $60.0 \%$ & $40.0 \%$ & \\
\hline -Precipitation & $52.9 \%$ & $47.1 \%$ & \\
\hline -Others & $42.9 \%$ & $57.1 \%$ & \\
\hline Contrast blush & $33.3 \%$ & $66.7 \%$ & 0.025 \\
\hline No contrast blush & $56.8 \%$ & $43.2 \%$ & \\
\hline Pseudoaneurysm & $25.0 \%$ & $75.0 \%$ & n.s. \\
\hline No pseudoaneurysm & $50.5 \%$ & $49.5 \%$ & \\
\hline Hemoperitoneum at $C T$ scan & $43.0 \%$ & $57.0 \%$ & n.s. \\
\hline
\end{tabular}

Number of quadrants with hemoperitoneum at CT scan

$\begin{array}{clll}->1 & 30.0 \% & 70.0 \% & 0.001 \\ -\leq 1 & 59.7 \% & 40.3 \% & \\ \text { INR (s) } & 1.11 \pm 0.15 & 1.59 \pm 1.02 & 0.001 \\ & 1.15(0.66-1.38) & 1.18(1.04-5.05) & \\ \text { INR > 1.5 s } & 11.8 \% & 88.2 \% & 0.002 \\ \text { INR < 1.5 s } & 48.5 \% & 51.5 \% & \\ \text { Fibrinogen (mg/dL) } & 221.06 \pm 57.54 & 172.76 \pm 62.17 & \text { n.s. } \\ & 216.00(156.00- & 175.00(26.00- & \\ & 401.00) & 260.00) & \\ \text { PLT/mm }{ }^{3} & 218.82 \pm 47.96 & 200.76 \pm 79.31 & \text { n.s. } \\ & 220.00(137.00- & 190.00(55.00- & \\ & 315.00) & 302.00) & \\ \text { Positive eco-fast } & 29.0 \% & 71.0 \% & 0.002 \\ \text { Negative eco-fast } & 59.1 \% & 40.9 \% & \\ \text { RBC transfusion at the ED } & 11.5 \% & 88.5 \% & <0.001 \\ \text { No RBC transfusion at the } & 53.0 \% & 47.0 \% & \end{array}$

ISS Injury Severity Score, $H R$ heart rate, SBP systolic blood pressure, ED emergency department, $B E$ base excess, Lac lactates, $H b$ hemoglobin, $R B C$ red blood cells, AAST American Association for the Surgery of Trauma, WSES World Society of Emergency Surgery, PLT platelet, $C B$ contrast blush, PSA pseudoaneurysms, INR International Normalized Ratio 
Table 6 Multivariate analysis of risk factors for OM as a definitive treatment

\begin{tabular}{lll}
\hline Variables & $p$ value & OR \\
\hline INR $>1.5 \mathrm{~s}$ & n.s. & $/$ \\
RBC transfusion in ED & n.s. & $/$ \\
$\mathrm{Hb} \leq 12 \mathrm{~g} / \mathrm{dL}$ & n.s. & $/$ \\
ISS $>25$ & 0.013 & 5.75 \\
Contrast blush & n.s. & $/$ \\
Positive e-fast & n.s. & $/$ \\
Quadrants with hemoperitoneum $>1$ & n.s. & $/$ \\
WSES IV & 0.029 & 7.22
\end{tabular}

ISS Injury Severity Score, ED emergency department, $R B C$ red blood cell, SI shock index, AAST American Association for the Surgery of Trauma, $\mathrm{Hb}$ hemoglobin, WSES World Society of Emergency Surgery, CB contrast blush, INR International Normalized Ratio

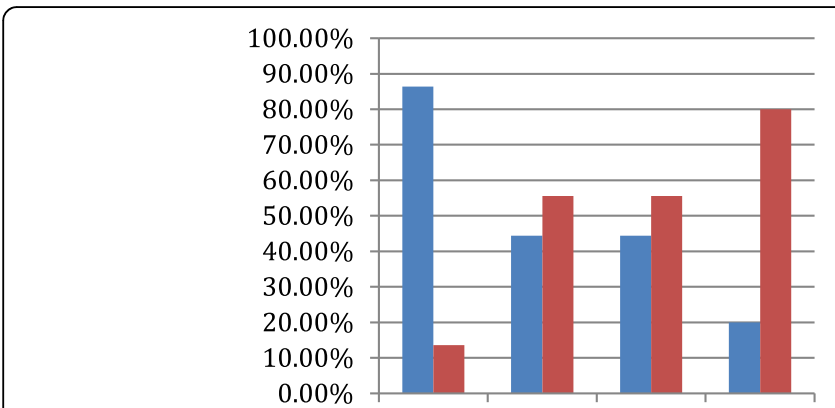

WSES 1 WSES 2 WSES 3 WSES 4

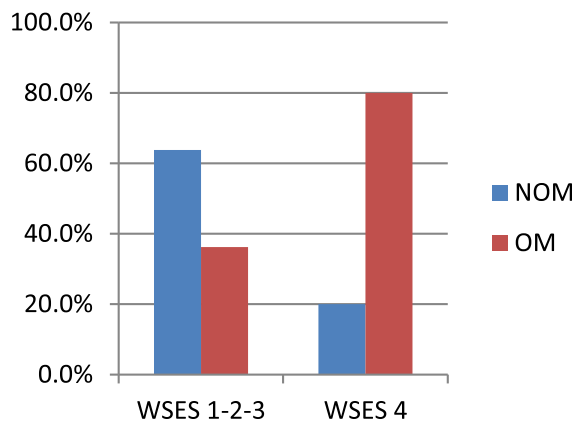

WSES 1-2-3 WSES 4

Fig. $2 \mathrm{OM}$ and NOM rate at the arrival of patient according to WSES splenic injury grade (NOM, Non Operative Management; OM, Operative Management)
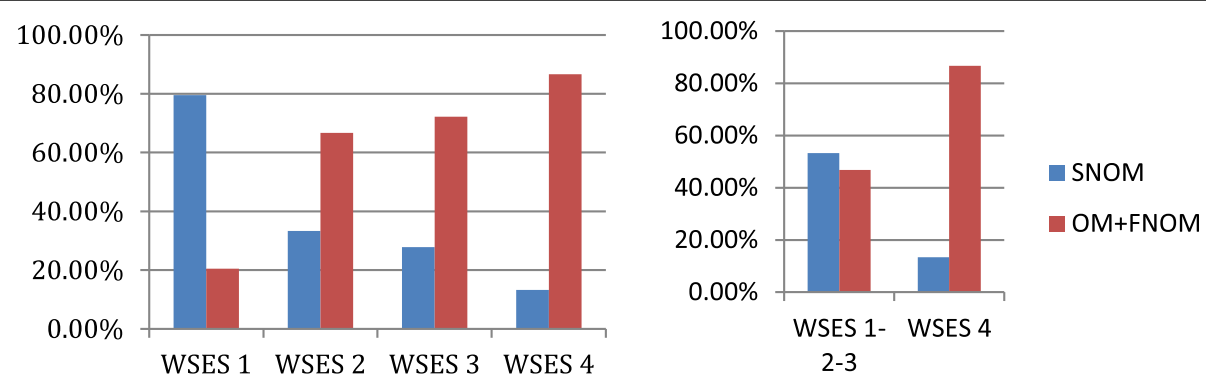

Fig. $3 \mathrm{OM}$ and NOM rate as a definitive treatment according to the WSES splenic injury grade (SNOM, Successful Non Operative Management; OM, Operative Management; FNOM, Failure of Non Operative Management)

\section{Conclusions}

The WSES classification is a good and reliable tool in the decision-making process in splenic trauma management.
NOM: Non-operative management; OIS: Organ Injury Severity Score; OM: Operative management; OR: Odds ratio; PSA: Pseudoaneurysm; RBC: Red blood cell; RR: Risk ratio; SBP: Systolic blood pressure; SI: Shock index; SNOM: Successful non-operative management; TC: Trauma center; WSES: World Society of Emergency Surgery

\section{Acknowledgements}

Not applicable

\section{Authors' contributions}

FeCo, PF, LM, and MC contributed to the manuscript conception, literature revision, and analysis. $L A, F a C a, S M, Y K$, and GLB helped with the analysis. 
FeCo and PF drafted the paper that was critically reviewed by MS, SO, MT, $N A$, and SM. All the authors read and approved the final version of the manuscript.

\section{Funding}

None

\section{Availability of data and materials}

Not applicable

\section{Ethics approval and consent to participate}

Not applicable

\section{Consent for publication}

Not applicable

\section{Competing interests}

The authors declare that they have no competing interests.

\section{Author details}

'General, Emergency and Trauma Surgery Department, Bufalini Hospital, Viale Ghirotti 268, 47521 Cesena, Italy. ${ }^{2}$ General, Emergency and Trauma Surgery Department, Papa Giovanni XXIII Hospital, Bergamo, Italy. ${ }^{3}$ General and Emergency Surgery Department, Sant'Anna University Hospital, Ferrara, Italy. ${ }^{4}$ Emergency and Trauma Surgery, Rambam Medical Centra, Haifa, Israel. ${ }^{5}$ General Surgery, Macerata Hospital, Macerata, Italy. ${ }^{6}$ Department of Clinical and Experimental Sciences, University of Brescia, Brescia, Italy. ${ }^{7}$ Emergency Surgery Department, Parma University Hospital, Parma, Italy.

Received: 30 January 2019 Accepted: 22 May 2019

Published online: 17 June 2019

\section{References}

1. Moore EE, Cogbill TH, Jurkovich GJ, Shackford SR, Malangoni MA, Champion HR. Organ injury scaling: spleen and liver (1994 revision). J Trauma. 1995; 38(3):323-4.

2. Peitzman $A B$, Heil $B$, Rivera $L$, Federle MB, Harbrecht BG, Clancy KD, Croce M, Enderson BL, Morris JA, Shatz D, Meredith JW, Ochoa JB, Fakhry SM, Cushman JG, Minei JP, McCarthy M, Luchette FA, Townsend R, Tinkoff G, Block EF, Ross S, Frykberg ER, Bell RM. Blunt splenic injury in adults: multiinstitutional study of the Eastern Association for the Surgery of Trauma. J Trauma. 2000;49(2):177-87.

3. Tinkoff G, Esposito TJ, Reed J, Kilgo P, Fildes J, Pasquale M, Meredith JW. American Association for the Surgery of Trauma Organ Injury Scale I: spleen, liver, and kidney, validation based on the National Trauma Data Bank. J Am Coll Surg. 2008;207(5):646-55.

4. Bhangu A, Nepogodiev D, Lal N, Bowley DM. Meta-analysis of predictive factors and outcomes for failure of non-operative management of blunt splenic trauma. Injury. 2012:43(9):1337-46.

5. Coccolini F, Montori G, Catena F, Kluger Y, Biffl W, Moore EE, et al. Splenic trauma: WSES classification and guidelines for adult and pediatric patients. World J Emerg Surg. 2017;12:40.

6. Haan JM, Bochicchio GV, Kramer N, et al. Nonoperative management of blunt splenic injury: a 5-year experience. J Trauma. 2005;58(3):492-8.

7. Smith HE, Biffl WL, Majercik SD, et al. Splenic artery embolization: have we gone too far? J Trauma. 2006;61(3):541-4.

8. Gavant ML, Schurr M, Flick PA, Croce MA, Fabian TC, Gold RE. Predicting clinical outcome of nonsurgical management of blunt splenic injury: using CT to reveal abnormalities of splenic vasculature. AJR Am J Roentgenol. 1997:168(1):207-12.

9. Bhullar IS, Frykberg ER, Tepas JJ 3rd, et al. At first blush: absence of computed tomography contrast extravasation in grade IV or $\mathrm{V}$ adult blunt splenic trauma should not preclude angioembolization. J Trauma Acute Care Surg. 2013;74(1):105-11

10. Skattum J, Naess PA, Eken T, et al. Refining the role of splenic angiographic embolization in high-grade splenic injuries. J Trauma Acute Care Surg. 2013, 74(1):100-3.

11. Requarth JA, D'Agostino RB Jr, Miller PR. Nonoperative management of adult blunt splenic injury with and without splenic artery embolotherapy: a meta-analysis. J Trauma. 2011;71(4):898-903.
12. Marmery $H$, Shanmuganathan $K$, Mirvis SE, Richard H, Sliker C, Miller LA, et al. Correlation of multidetector $\mathrm{CT}$ findings with splenic arteriography and surgery: prospective study in 392 patients. J Am Coll Surg. 2008;206:685-93.

13. Boscak AR, Shanmuganathan K, Mirvis SE, et al. Optimizing trauma multidetector $C T$ protocol for blunt splenic injury: need for arterial and portal venous phase scans. Radiology. 2013;268(1):79-88.

14. Schurr MJ, Fabian TC, Gavant M, Croce MA, Kudsk KA, Minard G, Woodman G, Pritchard FE. Management of blunt splenic trauma: computed tomographic contrast blush predicts failure of nonoperative management. J Trauma. 1995;39(3):507-12 discussion 512-3

15. Shanmuganathan K, Mirvis SE, Boyd-Kranis R, Takada T, Scalea TM Nonsurgical management of blunt splenic injury: use of CT criteria to select patients for splenic arteriography and potential endovascular therapy. Radiology. 2000;217(1):75-82.

16. Marmery $\mathrm{H}$, Shanmuganathan $\mathrm{K}$, Alexander MT, et al. Optimization of selection for nonoperative management of blunt splenic injury: comparison of MDCT grading systems. AJR Am J Roentgenol. 2007;189(6):1421-7.

17. Scarborough JE, Ingraham AM, Liepert AE, Jung HS, O'Rourke AP, Agarwal SK. Nonoperative management is as effective as immediate splenectomy for adult patients with high-grade blunt splenic injury. J Am Coll Surg. 2016;223(2):24958. https://doi.org/10.1016/j.jamcollsurg.2016.03.043. Epub 2016 Apr 23.

18. Olthof DC, van der Vlies $\mathrm{CH}$, Goslings JC. Evidence-based management and controversies in blunt splenic trauma. Curr Trauma Rep. 2017;3:32-7. https:// doi.org/10.1007/s40719-017-0074-2.

19. Cadeddu M, Garnett A, Al-Aneni K, et al. Management of spleen injuries in the adult trauma population: a ten-year experience. Can J Surg. 2006:49:386-90.

20. Skattum J, Loekke RJV, Titze TL, Bechensteen AG, Aaberge IS, Osnes LT, et al. Preserved function after angioembolisation of splenic injury in children and adolescents: a case control study. Injury. 2014;45:156-9.

\section{Publisher's Note}

Springer Nature remains neutral with regard to jurisdictional claims in published maps and institutional affiliations.

\section{Ready to submit your research? Choose BMC and benefit from:}

- fast, convenient online submission

- thorough peer review by experienced researchers in your field

- rapid publication on acceptance

- support for research data, including large and complex data types

- gold Open Access which fosters wider collaboration and increased citations

- maximum visibility for your research: over $100 \mathrm{M}$ website views per year

At BMC, research is always in progress.

Learn more biomedcentral.com/submissions 